\title{
Comparing How Ghana and Canada Succeeded in the adoption of the National Health Insurance (NHI): A Multiple Streams Approach
}

\author{
Issaka Sayi Abdul Hamid \\ Brock University, Canada
}

Email: issakahamid787@gmail.com

Received: May 29, 2016 Accepted: June 11, 2016 Published: June 22, 2016

doi:10.5296/jpag.v6i2.9529 URL: http://dx.doi.org/10.5296/jpag.v6i2.9529

\begin{abstract}
This paper examines the development of National Health Insurance (NHI) policy in Ghana and Canada using the multiple streams framework (MSF) as the theoretical lens. It undertakes a diachronic case study by comparing how Ghana and Canada eventually adopted national health insurance as a health care policy reform. The two countries introduced universal health care policy reforms, which, in the case of Ghana, necessitated the advent of the NHI policy in 2003. Though the two countries have different institutional settings, they both succeeded in their health care reforms. The study contends that the multiple streams framework is useful for explaining policy change in both developed and developing countries.
\end{abstract}

Keywords: National health insurance, Development, Health care, Reforms 


\section{Introduction}

This paper examines the development of National Health Insurance (NHI) policy in Ghana and Canada using the multiple streams framework (MSF) as the theoretical lens. Health outcomes are considered to be the fundamental test of government success in most political jurisdictions in both developed and developing countries (Adolino \& Blake, 2011, p. 234). Adequate utilization of healthcare services is important for maintaining quality of life. The economic productivity of any nation depends largely on the health of its labor force. This fact dictates that any nation desirous of improving its productivity must put in place policies to ensure adequate access to quality health care (Kamgina, 2008; Kouadio, 2008).

This paper, therefore, examines the health policy in a unitary and a federal state by using the multiple streams approach (Zahariadis, 2007, p. 87). The MSF, based on the "garbage can model" (Sabatier, 2007, p. 9), explains how policies are made by national governments under the condition of ambiguity (Zahariadis 2007, p. 65). The paper will specifically analyze the NHI policy in Ghana and Canada. My main argument is that, in spite of the institutional differences of both countries, they succeeded in adopting the NHI policy, thus, changes in the problem, policy, and politics streams, as well as their confluence by policy entrepreneurs, accounted for a significant shift in Ghana and Canada's health policy in 2003 and 1966, respectively. Existing literature on Canada's comparative health care policy is mostly on the United States, New Zealand, the United Kingdom, Australia, and other industrialized countries (Blankenau, 2001, Boothe, 2011; Marmor et al., 2010; Maioni, 1997; Tenbensel, 2008). There is little or no work on developing countries like Ghana. Thus, this paper begins to bridge this research gap.

Over the last two decades, health care delivery in Ghana has faced serious challenges mainly due to the introduction of the "cash and carry" policy in the 1980's. The "cash and carry" system was a full cost recovery policy for drugs in public health facilities. Under this system, health costs were paid up front before health care services were administered. Those without the means to pay were left without access to any form of formal health care services (Kusi-Ampofo et al. 2015). This resulted in a dramatic reduction in the utilization of health care services in Ghana. However, in 2003, a new health policy, the National Health Insurance (NHI), was introduced to address the tenuous problems of the "cash and carry" policy. This was an attempt to provide accessible, affordable and good quality health care to all Ghanaians especially the poor and vulnerable in society (Kusi-Ampofo et al. 2015; Singleton, 2006; Agyepong and Adjei, 2008; Carbone, 20011)

The Canadian government prior to the 1940s spent little effort addressing health reform. Jurisdictional uncertainty coupled with federal initiatives in the area of social policy became a source of tension between the provinces and the federal government (Maioni, 1997, p. 414). This uncertainty was reduced following the release of the report of the Royal Commission on Dominion-Provincial Relations in the 1940s. By 1966, Canada became one of the modern, industrialized countries in the world that adopted a national health insurance policy (Blankenau, 2001, p. 41; Maioni, 1997, p. 418). The body of literature in comparative perspective on Canada and Ghana's health care policy reform explaining why the NHIS was 
adopted in both countries is very scarce. Existing literature on Canada's comparative health care policy is mostly on United States, New Zealand, Canada and other industrialized countries (Tenbensel, 2008; Marmor et al., 2010; Maioni, 1997, Blankenau, 2001).

The study employs a most different case study research design because it involves an in-depth analysis taking into account the socio-political contextual causal factors of the different countries under study (March \& Stoker, 2010). This entails a small-N qualitative comparative historical analysis because it helps delineate the political forces that led to the adoption of the NHI policy in both countries. These include examining the historical proof through the utilization of process tracing and secondary literature in both Ghana and Canada. Ghana's health reform was initiated on the grounds that the NHI policy would be a necessary condition for utilization of health care delivery and maintaining quality of life (Darlinjog \& Suuklar, 2012, p. 2). Canada adopted NHI aimed at providing universal, accessible, and portable health care delivery (Irvine, 2005). The choice of Ghana and Canada is primarily based on the nature and institutional difference of both countries. While Ghana operates on the model of a unitary state with centralized power, Canada is a federal system with strong devolution. These key differences provide better criteria with which to compare the two distinct states. The rationale for undertaking this research is to critically examine why, despite the differences of the two countries in terms of their institutional settings, they both adopted the same policy.

This paper is structured in five parts as follows: the first section lays out the conceptual framework, the MSF that guides the study. The second section also explains the political forces that accounted for the significant shift in Ghana's health policy. Specific attention is paid to developments in the problem, policy, and political streams, and the way in which the key political entrepreneurs coupled the streams. The third section explains the processes through which Canada adopted the NHI policy in the light of the multiple streams approach. In the fourth section, the paper makes a comparative analysis between Ghana and Canada's journey towards the adoption of the NHI policy. The final section concludes the paper.

\section{The Multiple Streams Framework}

The MSF based on the "garbage can model" (Sabatier, 2007, p. 9), is useful in explaining the complexity of policy making process, and equally deals with how policies are made by national governments under the condition of ambiguity (Kingdon, 2003). The MSF theorizes at the systems level, primarily concerned with how certain issues get the attention of policy makers and end up becoming a national policy whiles others die in the policy making process. According to Kingdon (1995), the original proponent of the theory, three streams are identified in the framework as flowing through the political system: a problem stream, a policy stream and a politics stream (Zahariadis, 2007, p. 65). Each of the streams is conceptualized as largely separate from the other, with its own dynamics and rules (Zahariadis, 2007, p. 67). The key basic assumption of the theory is that policy makers operate under significant time constraints and that they need to strike while the iron is hot. This implies that all decisions are crises and that there is a sense of urgency in addressing them. Due to the urgency of time that this lens pays attention to, Kingdon argues that the 
logic of political manipulation, that is, those who manipulate and those who get manipulated aims that providing meaning and clarification in political struggle to create winners and losers (Kingdon, 1995). This assumption leads to the understanding of why some policy proposals received governmental attention whiles others die prematurely (Kingdon, 1995). In the case of both Ghana and Canada, for instance, there were numerous indicators such as high deaths, affordability, huge medical bills - Ghana (Kusi-Ampofo et al. 2015; Lazar et al., 2013), government fiscal crisis, new government with a clear vision for reforming health policy, and also the political will to initiate an action towards heath policy change - Canada (Lazar et al, 2013).

The problem stream comprises the various conditions that both policy makers and citizens want to be addressed. These problems may be issues such as health problems, inflation, environmental disasters, budget deficits, infant mortality, highway deaths, natural disasters etc. (Zahariadis, 2007). The problem identification consists of various conditions such as regularly repeated indicators, Focusing events and feedback highlights success and failures (Blankenau, 2001, p. 39; Zahariadis, 2007, p. 72). Kingdon (2003, pp. 109-110), notes that values and beliefs play substantial role in problem definition. Under such circumstances, people define conditions as problems by letting their values and beliefs, and by making comparisons and categories which contribute to the translations of the problems. EXAPLES

The policy stream consists of a "soup" of ideas that compete to win acceptance in policy networks (Kingdon, 2003, pp.116-117). In policy communities, various ideas are generated and marketed by policy analysts, politicians, and academic researchers. Problems receive serious attention on the basis of technical feasibility, affordability, and value acceptability (Kingdon, 2003; Zahariadis, 2007, p. 72) of available solutions.

The politics stream comprises three elements: the national mood, interest group activity, and turnover in government (Kingdon, 2003; Zahariadis, 2007, pp. 70-74). The national mood refers to the general perception that people hold on a particular policy issue. In addition to the above, legislative and administrative turnover frequently affects choice in quite dramatic ways, and thus provide the impetus for the policy window to either open or close (Blankenau, 2001, p. 39; Zahariadis, 2007, p. 73).

In a critical time, a window of opportunity is opened and the three separate streams converge (Kingdon, 1995, p.165). Policy entrepreneurs must act swiftly during the opened window to initiate an action as otherwise they have to wait until another window opens (Zahariadis, 2007, pp. 73-74).

Policy entrepreneurs are individuals or corporate actors who attempt to couple the streams at critical moments in time (Zahariadis, 2007, pp.70-74). Thus, the combination of all the streams into a single package enhances the probability of a particular policy being adopted by policy makers (Zahariadis, 2007, p. 65). Figure 1 below shows the MSF with the dependent variable, the independent variables, and the intervening variables. 


\section{Macrothink}
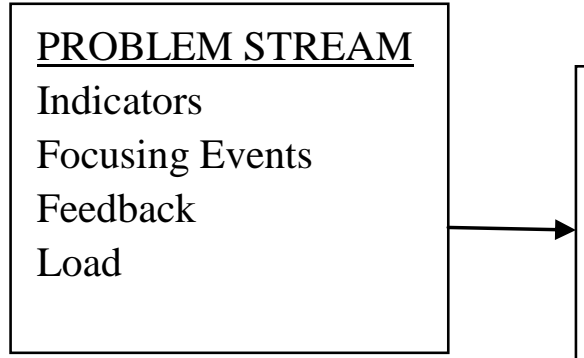

\section{POLICY WINDOW}

Coupling Logic

-Consequential

-Doctrinal

Decision style

-More Cautious

POLITICS STREAM

Partly Ideology

-Less Cautious

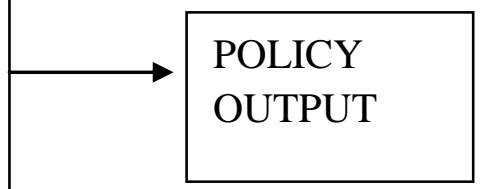

National Mood

\section{POLICY STREAM}

Value Acceptability

Technical Feasibility

-Access

-Mode

-Size

-Capacity

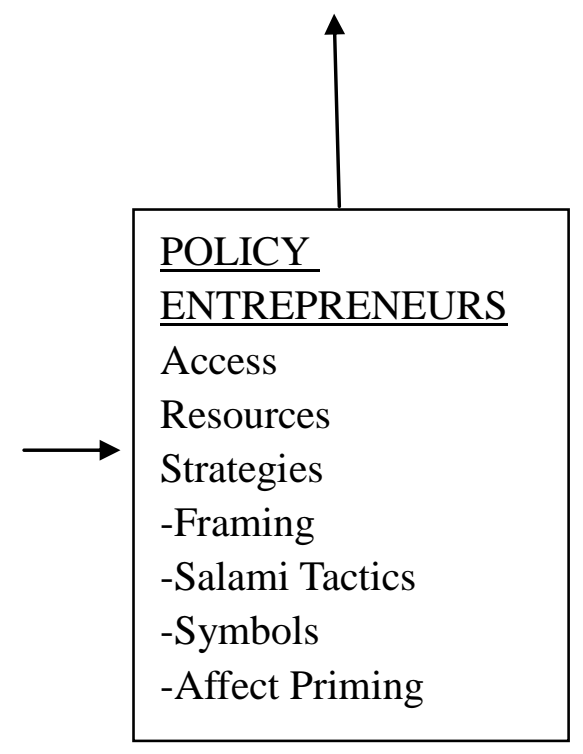

Figure 1. Diagram of the Multiple Stream Framework

Source: Adapted from Zahariadis (2007, p. 71)

\section{Political Forces That Accounted for a Significant Shift in Ghana's Health Policy}

Before Ghana attained independence, there was free healthcare for civil servants during colonial rule. In providing services for non-civil servants, user fees were charged in public health facilities (Asante et al, 2013, p.10; Assenso \& Wahab, 2008, pp. 300-301; Seddoh \& Arkoh, 2011, p. 5). However, the situation changed after Ghana gained independence in 1957. Further, due to the economic morass in the early 1970s, user fees were introduced as the state could no longer financially support the free healthcare system (Agyepong \& Adjei, 2008; Asante et al, 2013). The worsened economic condition continued in the 1970s and mid-1980s. During that period, Ghana's healthcare was characterized as a system in decline and deterioration. Nonetheless, due to the worsening economic conditions coupled with a lack of 
viable alternatives to resuscitate the economy, Ghana was forced to seek assistance from the World Bank and the International Monetary Fund (IMF) (Boafo-Arthur, 1999, p. 43). The IMF proposed some conditions that included: structurally adjusting the economy through liberalization, cutting of government expenditures, institutional reforms, and introduction of user fees in healthcare delivery (Boafo-Arthur, 1999, p. 43; Deitrich-O'Connor, 2010 ;). As part of the Structural Adjustment Program (SAP), the Ghana government substantially increased user fees for healthcare in the public sector. As a result of the user fees, in 1985, the Hospital Fee Regulation required patients of public health facilities to pay fully for their drugs (Asante et al, 2011). These conditions also resulted in the emergence of the "cash and carry" system which brought about the reduction in utilization of healthcare services (Asante et al, 2011; Singleton, 2006, p. 7).

\section{Multiple Streams Framework, Agenda Setting, and Policy Adoption}

\subsection{The Problem Stream}

The problem stream of the MSF comprises various conditions such as indicators - health care cost and infant mortality, focusing events-drawing attention to the problem, and policy feedback - what works and what does not work (Blankenau, 2001, p. 41; Zahariadis, 2007, p. 70). In the late 1980s, all these factors were evident in Ghana. After achieving independence, Ghana adored free health insurance as part of the socialist agenda. Health financing became free through general tax and donor support. However, due to the bad nature of the economy around that time, it became difficult to raise revenue for the funding of the insurance. The economic crises that existed with the lack of viable funding curtailed the existence of the insurance (Kwarting, 2011, pp. 2-3; Singleton, 2006, pp. 6-8). Important to this, Ghana's healthcare problem has always been framed in terms of quality, particularly in the 1980s. Quality is frequently touted as effectiveness in terms of service delivery. This framing was based on the recommendation of SAP by the IMF (International Monetary Fund) and the World Bank. Hence, the adoption of "cash and carry" policy was aimed at ensuring quality (Deitrich-O'connor, 2010). This preoccupation resulted when Ghana adopted the SAP due to its economic morass. However, there was a significant shift in the framing from quality to affordability and accessibility during 2000 (Singleton, 2006).

With respect to indicators, in the 1970s, a committee headed by Dr. Komotey-Ahulu was tasked to make proposals for the introduction of a health insurance scheme. This led to the enactment of the Hospital Fee Act 387 of 1971, which replaced the free health scheme introduced during the First Republic. However, following the 1972 military coup, the process of establishing health insurance was aborted. Responding to pressures from the popular Ghanaians, a Fee For Service (FFS) was introduced as an exemption mechanism to give free medical exams to some vulnerable diseases. As a result, in 1985, a Legislative Instrument (L.I. 1313)was passed into law and exemptions were granted for some selected public health diseases such as leprosy, as well as for antenatal and postnatal care (Seddoh \& Akor, 2012, p. 5). In the legislative instrument, there was no provision for emergency care for the poor and indigent due to the non-availability of financial resources.

Also, a study found that $84 \%$ of the patients eligible for exemption were not exempted under 
the FFS, which resulted in a drop in the utilization of the FFS from 1.9 percent to 0.3 percent (Seddoh \& Akor, 2012). In the midst of these consequences, proposals for the establishment of the NHI were considered again in the 1990s (Seddoh \& Akor, 2012). These proposals were made in an attempt to ameliorate the "cash and carry" system. On the basis of these proposals there were some discussions at both the national and subnational levels. The government, through the Ministry of Health, created a unit to establish health insurance as an alternative to "cash and carry" policy (Agyepong \& Adjei, 2008). A number of community based health insurance pilot projects were established as a pioneer of the NHI. Albeit, the pilot projects were not successful, the Social Security and National Health Insurance Trust (SSNIT) started planning for another centralized health insurance scheme to be run by a company called the Ghana HealthCare Company (Agyepong \& Adjei, 2008). The failure to bring a halt to the cash and carry system contributed to an infant mortality rate of 86 per 1000 live births by the end of 1989 (United Nations Development program, 2005; Singleton, 2006 as cited in Kusi-Ampofo et al., 2015).

A focusing event was also evident in the Ghanaian case that shaped the problem stream. Public outcry calling for the "cash and carry" policy to be scrapped turned out to be a focusing event as it directed attention towards the issue of NHI. Health professionals only attended to patients who paid up front, and this became a serious issue of discussion among Ghanaians. The consequences of these problems raised serious discontent among the Ghanaian populace. Both the media and the ordinary Ghanaian called for the "cash and carry" policy to be discarded (Agbeve, 1997).

\subsection{The Policy Stream}

The policy steam comprises a "soup" of ideas that compete to win acceptance in policy networks (Zahariadis, 2007, p. 72). In policy communities, ideas are generated and marketed by policy analysts, politicians, and academic researchers. The discredited "cash and carry" triggered several policy proposals, both at the national and the international level, looking for a viable solution. Some civil society groups and labor unions were part of presenting proposals such as the Trade Union Congress (TUC) (Seddoh \& Akor, 2012). As a result, the only proposal that came to the policy table was the NHI. This is because the NHI was perceived to be the best viable alternative to replace the cash and carry due to the benefits that some Ghanaians endured as a result of the Nkoranza experience (Kusi-Ampofo et al., 2015, p. 11)

On value acceptability and technical feasibility, the government initiated studies into alternative means of financing healthcare. A bilateral technical assistance contract was agreed upon by the government and a German firm was engaged to study the feasibility of creating a NHI program. The government then engaged a local consultant firm to carry out the studies but failed to follow up (Kwarting, 2011, p. 23). Interestingly, as a result of the failure on the part of government, a number of community based health insurance pilot projects were established as pioneers of the NHI.However, the pilot project died by 1999 without any formal reason (Agyepong and Adjei 2008). Subsequently, a unit was created by the Ministry of Health (MOH) to establish NHI as an alternative to the "cash and carry" policy. The unit 
focused its efforts and resources on consultancies and feasibility studies for a pilot social health insurance (SHI) scheme for the formal sector and organized groups such as cocoa farmers in the Eastern Region. However, the pilot scheme died without insuring anybody.

Following the demise of the pilot scheme, in 1992, the St. Theresa Catholic Mission Hospital based in Nkoranza also initiated the first Community Health Insurance (CHI) scheme. However, due to its shortfalls, such as absence of community ownership and a precarious financial position to ensure sustainability, the poor were excluded (Agyepong \& Adjei, 2008, pp. 150-160; Seddoh \& Akor, 2011, p. 5). This notwithstanding, the SSNIT started planning for another centralized health insurance scheme to be run by a company called the Ghana Health Company. Like the Eastern Region pilot, it never took off, despite some public expenditures on personnel, feasibility studies, and software (Agyepong \& Adjei, 2008, pp. 150-160). The piloted schemes received a high degree of acceptance among Ghanaians (Seddoh \& Arkoh, 2008, p. 11) as a health insurance solution in search of a window of opportunity.

Technical feasibility became a salient issue especially when the health insurance piloted by Nkoranza was proven to be workable. Ordinary Ghanaians started asking why the government was failing to undertake the initiative to carry out the program since that was seen to be the solution for the healthcare service problem. The solution had waited for the opportunity to rise to the top of the policy stream. However, events in the political stream, the problem stream and the opening of the window of opportunity must couple to allow for policy entrepreneurs to initiate a change.

\subsection{The Political Stream}

The politics stream, as described by the MSF, is shaped by the national mood, pressure group campaigns, and administrative turnover (Zahariadis, 2007, p. 73). The elements that were influential in forging the politics stream were the national mood and pressure group campaigns. As noted by Agbeve (1997), the "cash and carry" system became a salient political issue, as health professionals only attended to patients who made initial payment for the service. This resulted in unnecessary suffering and death, leading to demands that "cash and carry" policy be scrapped. This became a serious news story and there was a national outcry against the "cash and carry" system. As a result, discussion aimed at identifying a better alternative in healthcare delivery began to take shape (Singleton, 2006, p. 8). In the midst of the negative consequences of the "cash and carry system," health insurance became the only solution to ameliorate the outstanding problem (Mensa \&Appiah, 2012). Thus, the national mood began to change, and people began to question the ideology of the incumbent government. The incumbent National Democratic Congress (NDC) government claimed to believe in social democracy. However, the existing healthcare system did not align with this ideology. As a result, people started blaming the government for not being responsible enough to mitigate the problem. Interestingly, the date for the country's election was slated for December, 2000 (Frempong, 2012, p. 94). The 2000 general election was seen as a test on Ghana's democracy because the siting president was not contesting the election. The balloting was between the ruling government, the NDC, and the main opposition party, the 
NPP. Though several parties contested for the election, it was a two horse race between the two main contenders. The main opposition party, the NPP, made a campaign promise to abolish the cash and carry for which became a salient political issue in that election (NPP Manifesto 1996, p. 36)

\section{The Opening of the Policy Window and the Confluence of the Three Streams}

Policy windows are of short duration and are opened by compelling problems or events in the political or problem streams. Coupling takes place when the problem, policy, and politics streams are merged at critical moments (Zahariadis, 2007, pp. 65-74). Thus, a major policy change occurs only when policy entrepreneur(s) successfully take advantage of the opened window and couple the three streams together (Zahariadis, 2007, pp. 65-7).

In the case of Ghana's health policy adopted in 2003, the policy entrepreneur was J. A. Kuffour, the presidential candidate of the main opposition party, the New Patriotic Party (NPP). J. A. Kuffour was the one who effectively coupled the streams together. Assensoh \&Wahab (2008 302) noted that, "Kuffour promised the Ghanaian electorate that a win for them would mean the introduction and passing of a comprehensive health insurance for all residents of Ghana, instead of the much maligned "cash and carry" system instituted by the PNDC regime." The NPP party, having realized the salience of health insurance and the unacceptability of the discredited "cash and carry" system, promised to initiate an affordable healthcare system. The keenly contested election of 2000 was a two-horse race between the NDC and the NPP, despite the existence of other political parties (Debrah, 2005).

Kingdon distinguishes between "predictable windows" and "unpredictable windows' for reform. To him, predictable windows can be linked to the budget cycle, statutory requirements (examples include requirements for periodic legislative review or sunset provisions), and election cycle. For the unpredictable windows, the problem, policy, and political streams usually run in parallel with one another, however, at certain times, random events bring these streams together (Kingdon, 2003, p. 186-190). In the case of Ghana, the policy window opened when the NPP won the election in December 2000. This is because in the election cycle as indicated by Kingdon, a window opens because of change in political stream. Consequently, when the NPP assumed office in January 2001, President Kuffour, in an attempt to embark on an aggressive path towards fulfilling his promise (Atalinga, 2011, p. 48), appointed a Minister of Health to take charge in fulfilling the campaign promise. Quickly, the new minister inaugurated a taskforce under the auspices of the Director for Policy, Planning, Monitoring, and Evaluation (PPME) in the MOH (Agyepong \& Adjei, 2008, pp. 154). The policy outline developed by the task force was endorsed in June 2001 by the Ministry of Health. A reform was proposed on the two main sources of its funding. According to the reform, financing of the NHIS was to be by individual premium payments and a 2.5 percent National Health Insurance Levy to be collected using the same mechanisms as the already existing 12.5 percent Value Added Tax (VAT). When the policy was tabled in parliament as a draft bill, the National Democratic Congress (NDC), the main opposition party, walked out of parliament when it came to casting of votes on the issue (Alatinga, 2011, p. 49; Seddoh \& Arkoh, 2011, p. 8; Agyepong \& Adjei, 2008, pp.150-160). The major 
concern expressed by the NDC was the source of funding. In spite of the discontent expressed by the minority party, the NPP used its majority in parliament to pass the bill. The current NHIS in Ghana emerged from the NHI (Act 650) 2003 and NHI regulation (L.I 1809) 2004 (Atalinga, 2011, p. 49; Gobah \& Liang, 2011, p. 90).

\section{Political Forces that Accounted for a Significant Shift in Canada's Health Policy}

In the 19th and 20th centuries, Canada's health care service was based on fee for service (Marchildon, 2012, p. 22; McArthur et al., 1996, p.112). Canadians paid doctors, hospitals, pharmacists, and other health care providers before services were administered to them, and thus, user fees were the method for payment (Marchildon, 2012, p. 24; McArthur et al., 1996; Taylor, 2009, p. 28). However, for those who could not afford to pay for their care, there were three types of social safety nets: philanthropy, social assistance, and mutual aid (Marchildon, 2012; MacArthur et al., 1996; Taylor, 2009, p.28). In the 1930's, due to the economic depression that hit Canada, the general financial crisis affected all livelihoods, and the medical profession was no exception (Crichton et al., 1997 p. 8; Gray, 1991, p. 27; Maoini,1997, p. 414 Marchildon,2012, p. 11; MacArthur et al., 1996). The depression that plagued the country prompted medical organizations to react to the circumstances through the provision of some type of "first-dollar" health insurance for low income persons and the unemployed. Both the federal and provincial levels of government were under pressure to make such provisions (Mc Arthur et al., 1996; Taylor, 2009). The danger to health was matched only by the indignities suffered by individuals forced to appeal to municipal relief officers for authorizations to be admitted to hospitals (Gray, 1991; Taylor, 2009, p. 4). As a result, there were growing opinions at the grassroots level that were often expressed as "never again will I crawl on my hands and knees to a municipal official before I can be admitted to hospital" (Marchildon, 2012; Taylor, 2009). A 1933 survey conducted by the Canadian Medical Association (CMA) revealed that only a few municipalities were able to meet part of the costs. Thus, the burden of medical services was beyond the financial capacity of the municipalities (Marchildon, 2012; Taylor, 2009).

\section{Multiple Streams Framework, Agenda Setting and Policy Adoption}

\subsection{The Problem Stream}

The problem stream refers to the process by which problems are recognized and how conditions are defined (Kingdom, 2003, p. 19). It comprises the indicators, focusing event and policy feedback. By 1960, these factors were identified in Canada. Canada's healthcare policy was framed as a result of institutional factors to be under provincial jurisdiction and governments in all the provinces became involved in the provision of public health services in the last quarter of the $19^{\text {th }}$ century (Cassidy, 1945: 33-143, 452-3 as cited in Gray, 1991, p. 27). This provided power to the provincial government to execute health policies in their respective rights. Thus, various provinces designed different health policies that they deemed to fit their respective jurisdictions. Nevertheless, prior to the 1940 's, there was a significant shift in the framing of Canada's health policy from the provincial responsibility to the federal government responsibility. This is because the blaze trail from Saskatchewan has triggered Ottawa and the other provinces a hospital insurance in the federal with much diversity (Lazar 
eta. 2013). The report of the Royal Commission on Dominion - Provisional Relations suggested that the federal government had an important role to play in social security programs (Gray, 1991; Maoini, 1997, p. 414 Marchildon, 2012; Taylor, 2009). In addition, the success story of Saskatchewan's implementation of its health insurance also influenced a strong public opinion that the federal government could implement a national health insurance policy (Gray, 1991, p. 29; Marchildon 2012; Taylor, 2009).

With respect to indicators, in 1945, there was a federal-provincial conference to consider programs of social reforms. The conference produced a draft health care bill for the provinces; however, the plan was not enacted. It was seen by the provincial governments of Ontario and Quebec as a federal encroachment on the provincial authority (Marchildon, 2012; McArthur et al., 1996, p.113). Following the federal provincial conferences, proposals were made in which the National Health (hereafter called the Health Department) was formed by the actors due to the Saskatchewan blaze.This eventually led the conservative government to appoint a Royal Commission to make recommendations regarding Canada's health care situation (Marchildon, 2012; Taylor, 2009, p. 4). The Royal Commission recommended that the federal government introduce national medical care insurance (Crichton, 1997, p.10; Marchildon 2012; Taylor, 2009). The Commission reported that many Canadians were without adequate medical care, and some were overwhelmed with the cost and losses due to illness. Maternal mortality was very high, ranging from 2.9 per 1000 in Prince Edward Island, to 4.8 in New Brunswick. Also, they found that in 1940, there were 13,783 infant deaths. Equally shocking, tuberculosis was a serious disease that claimed the lives of 5,789 (Taylor, 1997, pp. 5-6).

Other conditions in the form of policy feedback were also evident. Following the passage of the Hospital Insurance and Diagnostic Service Act (HIDSA) in 1957, by 1961 all the provinces have adopted universal hospital insurance because the federal government was paying 50 percent of the average provincial costs (Blankenau, 2001, p. 41; MacArthur, 1997, p. 114). However, the main problem with the HIDSA was that services were insured and eligible for cost sharing only if they were provided in hospitals; there were no incentives to use less than expensive sites (McArthur, 1997, p. 114; Maioni, 1997; Marchildon, 2012). More importantly, developments in Saskatchewan served as focusing events (Blankenau, 2001, p. 41). In Saskatchewan, medical practitioners within the provinces embarked on a strike after the implementation of the medical care insurance in 1962 by the provincial government. The physicians refused to provide medical service except for emergency care. The strike lasted for over 23 days, which became a serious issue, thus, directing public attention towards the issue of national health. This was because the strike did not go well with the public and the media especially, and it hung for debates across the media (Crichton et al., 1997, p.9, Gray, 1991, Taylor, 2009). In the long run, the strike ended and Saskatchewan medical insurance survived (Gray, 1991; Marchildon, 2012, p. 115).

\subsection{The Policy Stream}

In Canada it was obvious that there were several policy proposals in search for viable solutions. The Rowell-Sirois Royal Commission, appointed in 1937, explored and envisaged action on how to provide "state medicine and state hospitalization or health 
insurance"(Proceedings of the Federal-Provincial Conference, 1995, p. 22 as quoted in Taylor, 2009 , p. 4). The Royal Commission provided advice and recommendation on how to solve the health problem (Marchildon, 2012, p.15, Taylor, 2009; Gray, 1991). They recommended a universal medical insurance similar to that of Saskatchewan (Marchildon, 2012, p. 99; Taylor, 2009; Gray, 1991; Maioni, 1997; MacArthur, 1996). Interestingly, by the time the commission began its work, all 10 provinces had implemented hospitalization programs and public opinion was strongly in favor of the public provision of physician insurance (Marchildon, 2012, p. 214). Given the recommendation of the final report of the commission, the provinces were expected to provide insurance plans that were comprehensive in benefits, with the federal government supporting 50 percent of the cost (Blankeneau, 2001, p. 42). Since the introduction of the national hospital insurance, technical feasibility became less of an issue (Blankenau, 2001). This is because it proved to be workable.

\subsection{The Political Stream}

In the political stream, events beyond the confines of the particular issue under investigation can be examined (Rowlands, 2007, p. 194). In the development of the Canadian national insurance, national mood, turnover in party leadership, and party composition were very influential under the political stream (Blankenau, 2001, p. 42). From 1939 onward, the conservative premier of Ontario suggested that a joint national health insurance program should be put on the agenda for the next federal-provincial conference. This was after the health care minister, Paul Martin, threatened to resign, and Prime Minister Ian Mackenzie agreed to the inclusion of the item. At the conference, a committee was established to study the issue of national health insurance (Gray, 1991, p. 36; Marchildon, 2012; Taylor, 2009). Under pressure from the provinces and the Co-operative Commonwealth Federation (CFF) and with strong public support for health insurance, the federal government made an offer in January 1956, but the terms of condition were not conducive to ready acceptance (Globe and mail 25 January 1956:1 as quoted in Gray, 1991, p. 36). Negotiations and political games continued between Ottawa and Ontario throughout 1956 and 1957, but the political costs of the delay began to mount, especially for the federal government. In 1957, an election year, the Liberal Party lost control of parliament to the conservatives, but managed to take control in 1963 as a minority government (Blankenau, 2001, p. 43; Gray, 1991, p. 43). With pursuit to champion the national health insurance and following the recommendations of the Royal Commission, Prime Minister Pearson called a federal-provincial conference in 1965 to discuss the proposals for a national medical-insurance scheme. Four principles were suggested: that the program should be a comprehensive range of medical services; that it should be universal, covering all residents; that benefits should be portable between provinces; and that it should be administered by a public agency (Gray, 1991, p. 43; Marchildon, 2012). The appointment of Judy LaMarsh as Minister of Health and Welfare by the Prime Minister Pearson led to a policy entrepreneurship. LaMarch fought to convince the minister of finance, Walter Gordon for money for the sponsorship of the program (Blankenau, 2001, p. 43). Both LaMarch and Gordon's role was instrumental as policy entrepreneurs in crafting the national health insurance bill and providing the political impetus for it (Blankenau, 2001, p. 43). 
The activities of political parties were also present to push for the national health insurance. The NDP, a progeny of the CCF, played a crucial role in the politics surrounding the health insurance. It was the CCF government in Saskatchewan that adopted the national health insurance. Thus, the minority liberal government came under pressure, especially when the NDP held the "balance of power" in the House of Commons in 1963 (Blankenau, 2001, p. 43; Maoini, 1997, p. 418). Also, the activities of pressure groups such as the CMA triggered the political streams. The CMA prolongs the strike lasted for about three weeks, that resulted in a death of a 9-month-old baby, raising serious concerns about health care service in the country (Crichton et al., 1997; Taylor, 2009). Earlier, the CMA had attempted to block anyone from the national health insurance, but their efforts were watered down, particularly when the Saskatchewan insurance survived (Marchildon, 2012, p. 151; Taylor, 2009). The problem, policy, and politics streams provide the opportunity for the window to open for power brokers and manipulators of problematic preferences to initiate a change.

\section{The Opening of the Policy window and the confluence of the three streams}

When the three separate streams converge, there are opportunities for actions (Rowlands, 2007, p. 94). The Saskatchewan success in the implementation of the health insurance program opened the window of opportunity for the policy entrepreneur like Tommy Douglas to initiate an action (Gray, 1991, p. 42; Maioni, 1997). The pressure kept mounting on the federal government to initiate the same form of health policy, especially when the impact of the program began to spread in the province of Saskatchewan. Health insurance became a desirable goal for the government when the Prime Minister Pearson appointed LaMarch and Gordon as the Minister of Health and Finance respectively. The ministers of the two ministries constituted the policy entrepreneurs (Blankenau, 2001, p. 43). Meanwhile, it was Gordon who initially resurrected the idea of health insurance at the federal level and mounted new strategies to make sure that the policy proposals had the support from the grassroots of the party officials of the liberals (Marchildon, 2012). Further, the federal-provincial conference in 1955 also fueled the agenda of the advocates for a national insurance policy (Blankenau, 2001; Gray, 1991; Marchildon, 2012). Though St. Laurent, The Prime Minister, was not enthused about the idea of national health insurance, his liberal party had always supported the program (Blankenau, 2001, p. 44). Subsequently, the Minister of Welfare, a supporter of the national health insurance threatened to resign if Laurent did not change his attitude (Blankenau, 2001).

That notwithstanding, there was a political wrangling among the liberals over timing. The Department of Finance struggled to design a strategy regarding health insurance (Marchildon, 2012, p. 81). As a result, LaMarch was demoted from health and welfare minister to secretary of state. The new minister for health was responsible for seeing Medicare to a conclusion. Gordon was also replaced by Mitchell Sharp in the Finance Ministry, who suggested a shift to the right in money matters (Marchildon, 2012, pp. 82-83). Interestingly, Gordon did not function in the new cabinet and started complaining that the "liberal government" was giving the impression of becoming increasingly conservative in its attitudes (Marchildon, 2012, p. 84). He condemned the liberal government for confusing the public about what they stood for in terms of the national health insurance. This caused another crisis for the cabinet. With 
conflicting and contradictory statements circulating about the future of Medicare, the Prime Minister himself stepped in, calling for an end to the cabinet wrangling (Marchildon, 2012; Taylor, 2009). Pearson pressed for a decision on health insurance in January 1966. There was an extended cabinet debate regarding the Medical Care Act. The Medical Care Act was passed in the House of Commons by a vote of 172 to 2. Mitchell Sharp remained opposed to the scheme and continued to speak publicly about the detrimental effects in 1967 on taxation levels, the economy, and the budget (Gray, 1991, p. 44). He predicted that Medicare would cost $\$ 1$ billion in its first year and would require an increased taxation-rate equivalent to $12 \%$ of personal income tax (Gray, 1991). At the cabinet meeting two days after his announcement Sharp was defeated. A group of pro-Medicare ministers stood behind the Prime Minister, and the announced date of July1, 1968 was confirmed for the policy (Gray, 1991).

\section{Ghana and Canada in Comparative Perspective}

This section focuses on comparing Ghana and Canada's experience with the adoption of the national health insurance policy. Ghana is a unitary state with decentralized governance. Strong power is vested in the hands of the centralized national authority that makes it easier for the government to implement a policy through the support of the legislature (Frimpong, 2012). On the other hand, Canada is a federal state with strong devolution of powers to the provincial governments. This sometimes makes it difficult for the federal government to push easily for a bill to be passed at the federal level (Maioni, 1997).

One of the apparent similarities between Ghana and Canada as far as their experience with health policy reform is concerned is that in both countries there was a general perception of crisis. In Ghana, the "cash and carry" was perceived to be a significant problem. The "cash and carry" was a full cost recovery policy for drugs, and health care costs were paid up front. Those without the means to pay were left without access to any form of health care service. This resulted in a dramatic reduction of utilization of health care services. As a result, there were unnecessary deaths and suffering as some health officials refused to attend to patients who were unable to pay instantly. These conditions received serious public attention and people began to call for the policy to be scrapped (Agbevi, 1997; Singleton, 2006; Yogesh, 2007). In Canada, health care services in the $19^{\text {th }}$ and $20^{\text {th }}$ centuries are based on fee for service. This means that Canadian's paid doctors, pharmacists, and other health care providers for discharging of health service. Due to the nature of health cost, there was rampant infant mortality, maternal mortality, and tuberculosis that claimed the lives of many Canadians. These conditions were considered callous and inhuman; therefore, provinces began to look for viable alternatives to address the problem (McArthur et al., 1996, p.112). The great depression around the 1930's, also influence the the thinking of phycisians in the country, thereby advocating for a better health in Canada (Lazar, 2013)

In addition, another similarity between the countries is that, in Ghana the piloting of the health insurance program by St. Theresa Catholic Mission based in Nkoranza and that of the SSNIT influenced the implementation of the NHI. The piloting by these two bodies aroused public sentiment about the benefit of the scheme particularly the vulnerable. The public, therefore, began to call for the full implementation of the health insurance program by the 
national government. Besides, in terms of feasibility, the general public realized that it was workable, particularly due to the Nkoranza experience (Agyepong \& Adjei, 2008; Seddoh \& Akor, 2011). Thus, external pressures mounted on the government for the adoption of the NHI policy. In Canada, the public perception of the Saskatchewan experience put intense pressure on the federal government to also adopt such a policy, as the national health care situation was seen as problematic. The success of the Saskatchewan experiment with both public hospital and medical care insurance served as an impetus for federal government action .Untold pressure was mounted on the federal government until it finally adopted the NHI policy (Gray, 1991, pp.35-36).

Another significant similarity was the framing of health policy in both countries. In Ghana around the 1980s, health care was conceived in terms of quality. This framing was touted due to the external inducement of the SAP that the country adopted. However, a significant shift occurred in the framing of the health care policy, from quality to affordability and accessibility because of the problems associated with the cash and carry. Political parties gave different interpretations about the better health policy in the country (Singleton, 2006). In Canada also, accessibility and affordability around the 1940's and 60's became part of the discussion of Canada's health reform policy. This was a big part of the health framing in Canada. Thus, there is a similarity here between Canada and Ghana. Both previously had private, pay-as-you-go systems that proved unworkable for many citizens.

Apart from the above similarity between Ghana and Canada, the two countries had different experiences as far as the NHI policy was concerned. One crucial difference between Ghana and Canada is that in the former it was the main opposition party, NPP that pledged for the implementation of the NHI policy when the window of opportunity opened during the 2000 elections. The party promised that if voted into office, it will scrap the "cash and carry" and implement the NHI policy. As a result,J. A. Kuffour, the policy entrepreneur, mounted a very skillful campaign during the 2000 elections that brought the party into office, and the policy was implemented (Assensoh \&Wahab, 2008; Debrah, 2005). In Canada, it was the liberal party that adopted the NHI at the federal level. The liberals adopted the policy due to the pressures from CCF/NDP, the perceived government in waiting. In fact, it was the NDP that pushed for the adoption of the health insurance policy in Saskatchewan. The liberal government at the federal level feared that it would lose to the NDP if it failed to implement the NHI policy. Unlike Ghana, where the opposition party campaigned against the cash and carry in favor of the NHI policy, in Canada it was the liberal government in power that push for its implementation at the federal level (Maioni, 1997; Marchildon, 2012;).

Again, one important difference between the two countries' reforms is that in Ghana, the adoption of the NHI was radical as compared to the incremental reform of Canada health policy. It took several years for Canada to introduce the NHI at the federal level. The situation was totally different from the Ghanaian experience. It was introduced by the government when the bill was passed in parliament. This could be attributed to the centralization of authority in the Ghanaian politics. The unitary system actually paved the way for the government in majority to push for the policy. In Canada, one would argue that the fragmented system impeded for the fast-track of the health policy process. From the 
above, it could be pointed out, there was an institutional hindrances in the quest for the NHI in Canada at the federal level. One might argue that countries use different approaches to the policy development process to achieve the same policy output.

Finally, when the opposition party, the NPP won the 2000 election and wanted to implement the NHI policy, the party tabled a drafted bill to parliament for consideration. The NDC, which was then the opposition, objected to the bill and walked out of parliament due to the source of funding for the NHI policy. Therefore, there was a debacle between the NPP and the NDC, albeit it was an external wrangling between the two forces (Agyepong \& Adjei, 2008; Alatinga, 2011; Seddoh \& Arkoh, 2011). The case was different in Canada; this is because there was an internal wrangling within the liberal party. Party heads and officials held different views about the implementation of the NHI policy at the federal level, particularly over the timing. The Department of Finance struggled to design a strategy regarding the NHI policy. This led to the demotion of the minister of finance, and a replacement took charge. The prime minister had to intervene to press for a decision on health insurance (Marchildon, 2012).

\section{Conclusion}

The objective of this paper was to make a comparative case study of Ghana's and Canada's health policy development using the MSF as a theoretical lens. The paper found that although, the two countries have different institutional settings, they both succeeded in the adoption of the NHI policy. While Ghana is a unitary state with strong decentralization, Canada is a federal state with strong devolution. In Ghana, the NHI policy was adopted in 2003, while Canada adopted the policy at the federal level in 1966. This study how the MSF can be used to explain how ideas can make it onto the policy agenda as policy proposals and how policy proposals can be adopted in countries with different institutional traditions. The two countries could also learn from each other since they have the same policy, specifically, Ghana could learn from Canada due to the fact that Canada had adopted the NHI for decades before Ghana finally adopted the policy. Policy leaning is very important, especially since both countries have adopted the NHI. Ghana could learn more from Canada since it adopted the policy several decades ago. The possible funding of the NHI could be a point of reference from Ghana since it is finding it difficult to sustain the NHI since its inception. The analysis strengthens the lens by paying specific attention to how the policy was adopted in both Ghana and Canada. Also, the paper found that the lens provides a useful description of the complexity of policy making, pointing out critical elements at the various stages that are often overlooked. I am considering a future comparison between both countries using the theory of policy diffusion. The Saskatchewan and Nkoranza experience is a very good example of examining how ideas and policies could be transformed from the subnational to national level. 


\section{References}

Adolino, J. R., \& Blake, C.H. (2011). Comparing public policies: Issues and choices in industrialized Countries. Second Edition. Washington: CQ Press.

Asante, F. A., Arhinful, D. K., Fenny A.P., Kusi, A. (2013) NHI Country Case Study Report. GhanaHealthInc.P1-18.www.Healthinc.Eu/Pdf/Isser-Ghana-Nhis-Case-Study-ReportPdf[acce ss online 12/06/2013]

Assensoh, A., B., Wahab, H. (2011). A Historical-Cum-Political Overview of Ghana's National Health Insurance Law. Africa and Asia Studies. 7. 289-306.

Agyepong, I. A., \& Adjei, S. (2008): 'Public social policy development and implementation': A case study of Ghana national health insurance scheme. Health Policy and Planning, 23 (2), $150-160$.

Ayee, Joseph R. A. 1994. An Anatomy of Public Policy Implementation: The Case of Decentralization Policies in Ghana.Aldershort: Avebury Press.

Agbeve E. (1997).The impact of cash and carry on Health Care delivery at the Ho Government Hospital- Legon: University of Ghana, M.B.A. Thesis (Unpublished).

Alatinga, K.A. (2011). An Assessment of the Health Reform Policy Process in Ghana: The case of the national health insurance policy process. World J Young Researchers, 1(4), 45-53.

Boafo-Arthur, K. (1999).Ghana: Structural Adjustment, Democratization and the Politics of Continuity. African Studies Review. 49 (2), 41-72.

Blankenau, Joe. (2001). The Fate of National Health Insurance in Canada and the United States: A Multiple Streams Explanation. Policy Studies Journal. 29(1), 38-55.

Brunner, S. (2008). Understanding policy change: Multiple streams and emissions trading in Germany. Global Environmental Change 18 (2008) 501- 507.

Crichton, A., Robertson, A., Gordon, C., Farrant, W. (1997). Health Care: A community Concern? University of Calgary Press.

Dalinjog, P. A., \& Suuklar, A. (2012): The national health insurance scheme: perception and experiences of health providers and clients in two districts of Ghana. Health Economic Review 2(13), 1-13.

Deitrich-O'connor, F. (2010). An Evaluation of the National Health Insurance Scheme in Ghana. University Of Guelph, 2010. www.Academia.Edu/..../An Evaluation of the National Health Insurance [Online Access 5dec.2013].

Debrah, E. (2005). The Electoral Process and the 2000 General Elections in Ghana. Liberal Democracy and its Critics in Africa: Political Dysfunction and the Struggle for Social Progress. New York and Pretoria: Codersia, 25-48.

Frempong, A. K. D. (2012). Electoral politics in Ghana's Fourth Republic:In the context of post-cold War Africa.yamens Press Limited.Accra,Ghana 


\section{Macrothink}

Journal of Public Administration and Governance ISSN 2161-7104

Gray, G. (1991). Federalism and Health Policy: The Development of Health Systems in Canada and Australia. University of Toronto Press.

Irvine, B. Ferguson, S. \& Cackett, B. (2002). Backgroud Briefing: The Canadian health care system. Civitas Foundation, 2.

Kouadia, A., Monsan, V., Gbonje, M. (2008). Social Welfare and Demand for Healthcare in the Urban Areas of Coted' Ivoire. AERC Research Paper, 181.

Kwarteng, E. (2011).National Health Insurance Scheme in Ghana:Experiences and Challenges of of WASSA West Health Insurance Scheme. A Dissertation Submitted to the Institute for Development Studies of the faculty of Social Sciences, University of Cape Coast. $1-93$

Kingdon, J.W.(1995). Agendas, Alternatives and Public Choices, 2nd ed. (New York).

Mensah, K., Appia, K.O. (2012). Political Marketing: The Emergence of J.A., Kuffour as a Man Made President. Journal of Business and Enterprise Development, (1)1

Ministry of Health Ghana (2004a), Legislative Instrument on National Health Insurance, Accra: National parliament of Ghana press.

McArthur, W., Ramsay, C., Walker, M. (1996). Healthy Incentives: Canadian Health reform in an International Context. The Fraser Institute Vancouver, British Colombia, Canada.

Marchildon, G., P. (2012). Making Medicare: New perspectives on the History of Medicare in Canada. University of Toronto Press.

Maioni, A. (1997). Parting at the Crossroads: The Development of Health Insurance in Canada and the United States, 1940-1965. Comprative Politics 29 (4), 411 - 431.

Ninsin, K.A. (1987).Ghanaian Politics After 1981: Revolution or Evolution? Canadian Journal of African Studies. 21 (1), 17-37.

Rahman, A., S. (2011). Health Sector Reform in Ghana. Haskyne school of Business, University of Calgary.www.haskayne.uccalgary.ca/.../-health\% 20 cane $\% 20$ forum $\%$ 2011[online][access on the $5^{\text {th }}$ December 2013].

Rossister, W., Price, L. (2013) Local economic strategy development under Regional Development Agencies and Local Enterprise Partnerships: Applying the lens of the multiple streams framework.Local Economy 28(7-8), 852-862.

Ridde, V. (2009). Policy Implementation in an African State: An Extension of Kingdon's multiple-Streams Approach.Public Administration 87(4), 938-954

Seddoh, A., \& Akor, S. A. (2012): Policy initiation and political levers in health policy: Lessons from Ghana's health insurance. BMC publish health 12(10), 2-11.

Singleton, J. (2006). "Negotiating Change: An Analysis of the origins of Ghana's N.H.I Act". Honors Projects. Paper 4. 


\section{Macrothink}

Journal of Public Administration and Governance ISSN 2161-7104 2016, Vol. 6, No. 2

Sabatier, Paul A. (ed). (2007). Theories of the Policy Process. 2nd Edition. Bouler: Westview Press.

Seddoh, A., \& Akor, S. A. (2012): Policy initiation and political levers in health policy: Lessons from Ghana's health insurance. BMC publish health 12(10), 2-11.

Singleton, J. (2006). "Negotiating Change: An Analysis of the origins of Ghana's N.H.I Act". Honors Projects. Paper 4.

Taylor, M., G. (2009). Health Insurance and Canadian Public Policy. McGill-Queen's University Press.

Yogesh, R. (2007). The Political Development of the Ghana National Health Insurance System: Lessons in Health Governance.Bethesda.MD: Health Systems 20/20. Project Abt Associations In.

Zahariadis, Nikolaos. (2007). “The Multiple Streams Framework: Structure, Limitations, Prospects, in Sabatier, Paul A. (ed). (2007). Theories of the Policy Process. 2nd Edition. Bouler: Westview Press.

\section{Copyright Disclaimer}

Copyright for this article is retained by the author(s), with first publication rights granted to the journal.

This is an open-access article distributed under the terms and conditions of the Creative Commons Attribution license (http://creativecommons.org/licenses/by/3.0/). 